\title{
FIRST RECORD OF EXOTIC AMUR CATFISH, SILURUS ASOTUS (ACTINOPTERYGII: SILURIFORMES: SILURIDAE), IN THE TIBET STRETCH OF THE LANCANG RIVER, CHINA
}

\author{
Ting-Bing ZHU, Jun HUANG, Xu-Ge WANG, and De-Guo YANG* \\ Key Laboratory of Freshwater Biodiversity Conservation, Ministry of Agriculture of China, Yangtze River Fisheries \\ Research Institute, Chinese Academy of Fisheries Science, Wuhan, China
}

Zhu T.-B., Huang J., Wang X.-G., Yang D.-G. 2018. First record of exotic Amur catfish, Silurus asotus (Actinopterygii: Siluriformes: Siluridae), in the Tibet stretch of the Lancang River, China. Acta Ichthyol. Piscat. 48 (2): 205-207.

\begin{abstract}
A single specimen of exotic Amur catfish, Silurus asotus Linnaeus, 1758, was captured by gillnet in the Tibet stretch of the Lancang River for the first time. (The Lancang River is an international river and in its lower course is also known as the Mekong River.) It is the first record of this fish species in eastern Tibet. The most possible pathway of the Amur catfish introduction into the Tibet stretch of the Lancang River was a humanmediated release known as life liberation activities or life release ceremony.
\end{abstract}

Keywords: Silurus asotus, exotic fish, the Lancang River, Mekong River, Tibet, life release ceremony

\section{INTRODUCTION}

The Lancang River is a big international river in Asia. The Lancang River in its lower course is also known as the Mekong River. The Tibet stretch of the Lancang River is about $509 \mathrm{~km}$ and its elevation above the sea level exceeds $2000 \mathrm{~m}$. Due to the high altitude environment, the fish fauna in the Tibet stretch of the Lancang River has been poorly studied. Only seven native fish species were recorded in this area (Anonymous 1995):

- Schizothorax lantsangensis Tsao, 1964

- Schizopygopsis anteroventris Wu et Tsao, 1989

- Ptychobarbus kaznakovi Nikolskii, 1903

- Triplophysa brevicauda (Herzenstein, 1888)

- Triplophysa stoliczkai (Steindachner, 1866)

- Triplophysa stenura (Herzenstein, 1888) and

- Pareuchiloglanis gracilicaudata (Wu et Chen, 1979)

The Amur catfish, Silurus asotus Linnaeus, 1758, is widely distributed in China, Japan, the Korean Peninsula, and Russia (Froese and Pauly 2018). In China, the Amur catfish is an economically important fish that is mainly cultured in Sichuan, Guangdong, Hubei, and Liaoning provinces. The currently known distribution records of the species in the main inland rivers of China are summarized in Fig. 1. The Amur catfish has been recorded from the Lhasa River, but is not recorded from other parts of Tibet (Chen and Chen 2010). In this paper, the first occurrence of exotic Amur catfish is reported from the Tibet stretch of the Lancang River.

\section{MATERIAL AND METHODS}

A single specimen of Amur catfish was sampled (Fig. 2) using gillnet (length $10 \mathrm{~m}$, height $1.5 \mathrm{~m}$, mesh size $0.4 \mathrm{~cm}$ ) on 15 September 2017. The sampling site $\left(30^{\circ} 52^{\prime} 54.4656^{\prime \prime} \mathrm{N}, 97^{\circ} 21^{\prime} 1.7892^{\prime \prime} \mathrm{E}\right.$; elevation $3123 \mathrm{~m}$ above sea level) was in the shallow water near the bank. The surface water temperature was $13.5^{\circ} \mathrm{C}$, the flow rate was $1.1 \mathrm{~m} \cdot \mathrm{s}^{-1}$, and the dissolved oxygen was $7.07 \mathrm{mg} \cdot \mathrm{L}^{-1}$.

\section{RESULTS AND DISCUSSION}

The specimen (Fig. 3) was $214 \mathrm{~mm}$ in standard length. The other morphometric and meristic characteristics are shown in Table 1. This is the first record of this fish species in the Tibet stretch of the Lancang River.

Amur catfish might be introduced into the Lancang River during life liberation activities, known also as a life release ceremony, a custom maintained and practised for thousands of years. During life liberation activities, the local people would buy live fish from the market and release them into a river. Therefore the demand for live fish during life liberation activities is dramatically increasing. On the other hand, religious beliefs of the local people prohibit them from fishing because living aquatic organisms (like the terrestrial ones) are treated as sacred. Therefore, a large amount of exotic fish products including Amur catfish from the lowland areas of China has been introduced into Tibet waters in recent years. On the other hand, the local people are less aware of the threat that exotic fish may pose to 


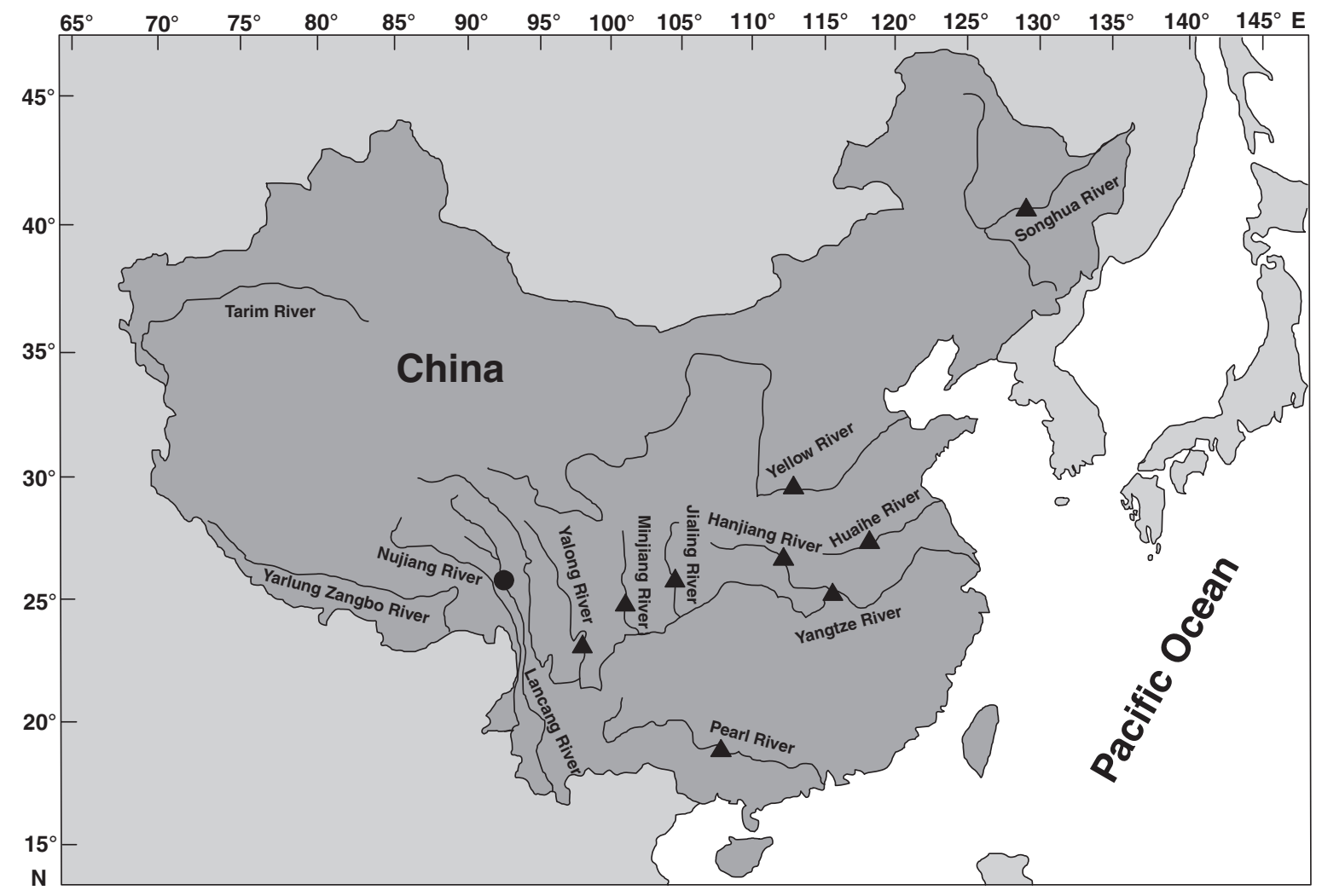

Fig. 1. Geographical distribution of Amur catfish, Silurus asotus, in the main inland rivers of China; black dot represents the new record from the Lancang River, triangles mark previous records

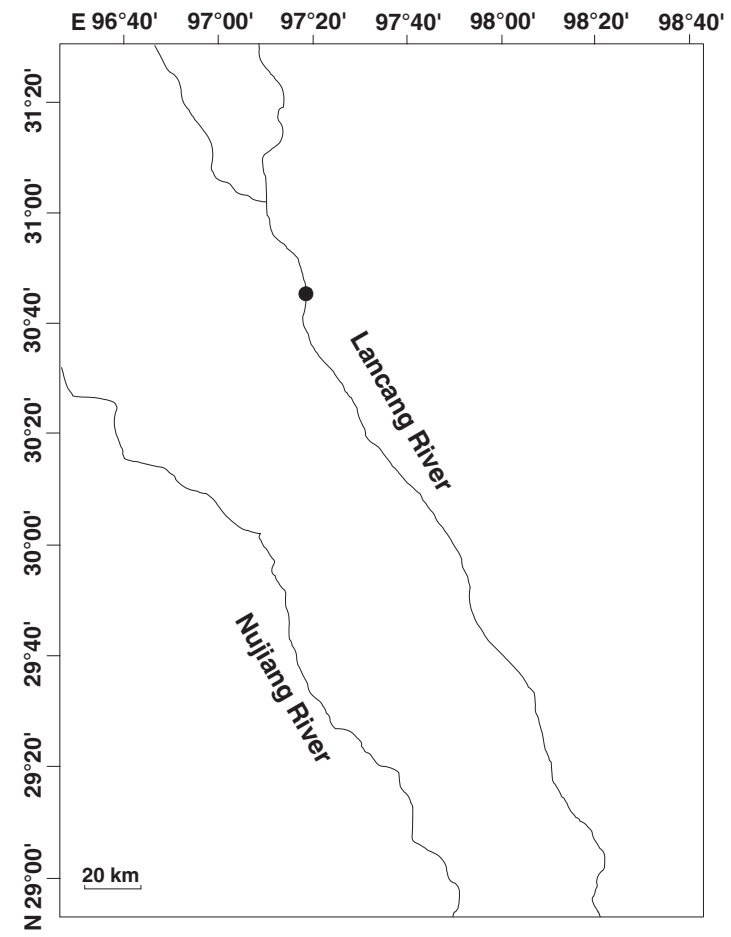

Morphometric and meristic characteristics of Amur catfish, Silurus asotus, caught in the Tibet stretch of the Lancang River, China

\begin{tabular}{lcc}
\hline \multicolumn{1}{c}{ Character } & $\begin{array}{c}\text { Morphometric } \\
\text { value }[\mathrm{mm}]\end{array}$ & Meristic count \\
\hline Total length & 236 & \\
Standard length & 214 & \\
Head length & 47 & \\
Head width & 34 & \\
Eye diameter & 5 & \\
Maximal body depth & 36 & \\
Maximal body width & 26 & \\
Mouth width & 24 & \\
Caudal peduncle length & 12 & \\
Dorsal fin length & 6 & \\
Anal fin length & 116 & 78 \\
Dorsal fin rays & & I, 10 \\
Anal fin rays & & I, 10 \\
Ventral fin rays & & \\
Pectoral fin rays & &
\end{tabular}

Fig. 2. A close-up map of the Tibet stretch of the Lancang River; black dot marks the sampling site of Amur catfish, Silurus asotus 


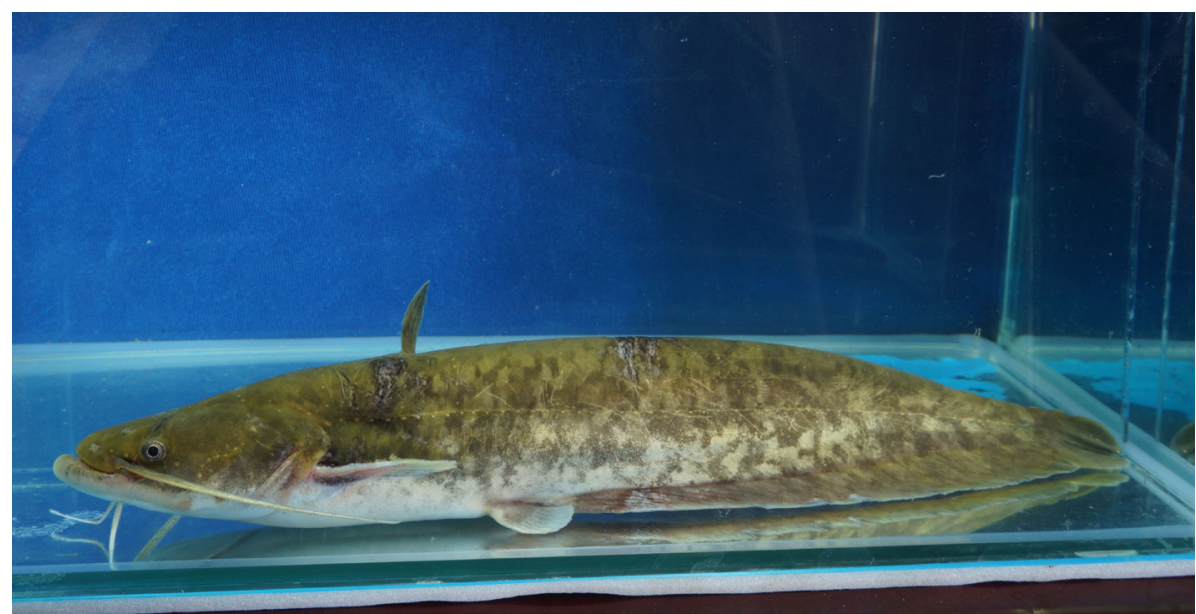

Fig. 3. The Amur catfish, Silurus asotus, caught in the Tibet stretch of the Lancang River, China

the local ecosystems and therefore they are determined to release all kinds of fish that are available on the market.

Amur catfish may have a negative impact on the ecology of the river system. Amur catfish is carnivorous and highly adaptable to various environments (Chu et al. 1999). Historically, there were no carnivorous fishes in the Tibet stretch of the Lancang River (Anonymous 1995). So it is reasonable to presume that individuals of the Amur catfish present in this area may form an established population easily and may exert huge predation pressure on the native fish species.

It is high time to build up the awareness in the local population about the invasion of Amur catfish and also to exert pressure on the policymakers to stop the practice of introducing the exotic species into the Lancang River.

\section{ACKNOWLEDGEMENTS}

This research was supported by the Finance Special Fund of Chinese Ministry of Agriculture (Fisheries resources and environment survey in the key water areas of Tibet).
REFERENCES

Anonymous 1995. [Fishes and fish resources in Xizang, China.] Bureau of Aquatic Products, Tibet, China. China Agriculture Press, Beijing, China. [In Chinese with English abstract.]

Chen F., Chen Y.-F. 2010. Investigation and protection strategies of fishes of Lhasa River. Acta Hydrobiologica Sinica 34 (2): 278-285. [In Chinese with English abstract and keys.]

Chu X.-L., Zheng B.-S., Dai D.-Y. 1999. [Fauna Sinica - Osteichthyes: Siluriform.] Science Press, Beijing, China. [In Chinese.]

Froese R., Pauly D. (eds.) 2018. FishBase. [Version 02/2018] www.fishbase.org

Received: 31 January 2018

Accepted: 20 March 2018

Published electronically: 30 June 2018 
